\title{
Clinical pharmacological studies of amoxycillin: effect of probenecid
}

\author{
R. BARBHAIYA, R. N. THIN, P. TURNER, AND J. WADSWORTH \\ From the Departments of Clinical Pharmacology and Genital Medicine and the Computing Unit for \\ Medical Sciences, St Bartholomew's Hospital, London
}

SUMMARY In a study of eight, healthy, adult volunteers given $3 \mathrm{~g}$ amoxycillin with or without $1 \mathrm{~g}$ probenecid, significantly higher peak plasma levels of amoxycillin were recorded in the presence $(34.96 \mu \mathrm{g} / \mathrm{ml})$ of probenecid than in its absence $(22.72 \mu \mathrm{g} / \mathrm{ml})$. When plasma levels were plotted against time the mean area under the curve was significantly greater for subjects given probenecid than for those given amoxycillin alone. These findings suggest that $3 \mathrm{~g}$ amoxycillin plus $1 \mathrm{~g}$ probenecid provide better bioavailability than $3 \mathrm{~g}$ amoxycillin alone. The plasma levels obtained were several times higher than the minimum inhibitory concentrations (MICs) of most strains of gonococci. Plasma levels in excess of the MICs for most strains were maintained for eight hours with both regimens, but the higher levels in the presence of probenecid support the better clinical results previously reported with this regimen.

\section{Introduction}

Amoxycillin is a semisynthetic penicillin similar in chemical structure and spectrum of activity to ampicillin (Sutherland et al., 1972) but is much better absorbed after oral administration (Croydon and Sutherland, 1971; Gordon et al., 1972). Probenecid competes with penicillins and other organic anions for renal secretion, resulting in higher plasma levels of penicillin when they are administered together (Burnell and Kirby, 1951; Vitti et al., 1974). Probenecid has been used together with ampicillin and amoxycillin for single-dose therapy for gonorrhoea (Karney et al., 1974; Thin et al., 1977). To investigate this further, plasma levels achieved after a dosage of $\mathbf{3} \mathrm{g}$ amoxycillin with or without concurrent administration of $1 \mathrm{~g}$ probenecid were estimated in healthy volunteers. In view of the uncertain fasting state of patients receiving the antibiotic therapy for gonorrhoea and the small effect of food on plasma levels of amoxycillin (Neu and Winshell, 1971) the kinetic study was carried out in non-fasting healthy volunteers.

Address for reprints: Professor P. Turner, Department of Clinical Pharmacology, St Bartholomew's Hospital, London EC1A 7BE

Received for publication 6 October 1978

\section{Materials and methods}

The clinical pharmacological studies were conducted in eight healthy adult volunteers (age 22-26 years, weight $60-80 \mathrm{~kg}$ ), all of whom gave informed consent. All subjects were shown by medical examination to be in good physical condition with normal blood and urine laboratory values. No subject had a history of allergic reactions to penicillins or cephalosporins. No other medication was taken by the subjects during the study.

Four subjects received $3 \mathrm{~g}(1 \mathrm{~g} \times 3)$ amoxycillin with $1 \mathrm{~g}$ probenecid, and the other four received the same medication without probenecid. One week later the subjects were given the treatment they had not received during the first week. The treatment was administered orally with $100 \mathrm{ml}$ water at least two hours after a standard breakfast of fruit juice and toast, and no food was allowed thereafter for four hours.

Blood samples were collected just before (zero hour) and at $1 / 2,1,1 \frac{1}{2}, 2,3,5,6$, and 8 hours after the antibiotic administration. Plasma samples obtained were kept frozen at $-20^{\circ} \mathrm{C}$ until assayed by a fluorimetric assay (Barbhaiya et al., 1977). A plot of the time course versus plasma levels of amoxycillin with or without probenecid was obtained for each subject, and from this the area under the curve (AUC) between zero and eight hours was calculated. 
The AUC was taken as a measure of relative absorption of amoxycillin in the absence and presence of probenecid. Paired $t$ tests were used to assess the significance of within-subject differences and the optimal concentration/time curves were calculated for each subject using a least-squares, fitting technique.

\section{Results}

Plasma concentrations of amoxycillin achieved in each subject after administration of a single oral dose of $3 \mathrm{~g}$ amoxycillin with or without concurrent administration of $1 \mathrm{~g}$ probenecid are presented in Table 1. In the absence and presence of probenecid mean peak plasma amoxycillin levels were achieved at three hours and ranged from one to four hours. The mean peak plasma level for amoxycillin was significantly higher when probenecid was administered $(34.96 \mu \mathrm{g} / \mathrm{ml})$ than that achieved without administration of probenecid $(22 \cdot 72 \mu \mathrm{g} / \mathrm{ml})$ $(t=3 \cdot 62: \mathrm{P}<0 \cdot 01)$. The peak plasma concentrations ranged from $23 \cdot 20-62 \cdot 00 \mu \mathrm{g} / \mathrm{ml}$ in the presence of probenecid and from $15 \cdot 34-32.46 \mu \mathrm{g} / \mathrm{ml}$ in its absence (Table 1).

The mean area under the curve was significantly higher in the presence of probenecid than that obtained in its absence in each of the eight subjects (paired $t$ test $=6 \cdot 13 ; \mathrm{P}<0.001$ ). The mean AUC without probenecid was $128.93 \pm 6 \cdot 13$ and with probenecid $208 \cdot 55 \pm 9 \cdot 22$. The AUC ranged between $170 \cdot 84-233 \cdot 29$ and $115 \cdot 65-165 \cdot 66$ in the presence and absence of probenecid respectively (Table 2 ).
Table 2 Area under the concentration/time curve for amoxycillin with and without probenecid

\begin{tabular}{|c|c|c|}
\hline \multirow[b]{2}{*}{ Subject no. } & \multicolumn{2}{|c|}{$\begin{array}{l}\text { Area under concentration/time curve for } \\
\text { amoxycillin }\end{array}$} \\
\hline & With probenecid & Without probenecid \\
\hline $\begin{array}{l}1 \\
2 \\
3 \\
4 \\
5 \\
6 \\
7 \\
8 \\
\text { Mean } \pm \text { SEM }\end{array}$ & $\begin{array}{l}233 \cdot 29 \\
170 \cdot 84 \\
242 \cdot 24 \\
222 \cdot 14 \\
225 \cdot 90 \\
179 \cdot 69 \\
199 \cdot 74 \\
199 \cdot 64 \\
208 \cdot 55 \pm 9 \cdot 22\end{array}$ & $\begin{array}{l}115 \cdot 65 \\
165 \cdot 66 \\
130 \cdot 63 \\
139 \cdot 94 \\
109 \cdot 69 \\
114 \cdot 84 \\
139 \cdot 99 \\
115 \cdot 29 \\
128 \cdot 93 \pm 6 \cdot 72\end{array}$ \\
\hline
\end{tabular}

\section{Discussion}

Several studies have compared the clinical pharmacology of amoxycillin and ampicillin after oral administration and have uniformly demonstrated significantly better absorption levels of amoxycillin (Gordon et al., 1972; Sutherland et al., 1972). The plasma levels of these antibiotics are considerably raised in the presence of probenecid. The present study shows that $3 \mathrm{~g}$ amoxycillin achieves higher plasma levels in the absence of probenecid than those reported for $3.5 \mathrm{~g}$ ampicillin with $1 \mathrm{~g}$ probenecid and equivalent peak levels to those reported for $2 \mathrm{~g}$ amoxycillin with $0.5 \mathrm{~g}$ probenecid (Vitti et al., 1974). The mean plasma levels obtained in eight subjects given $3 \mathrm{~g}$ amoxycillin

Table 1 Concentration of amoxycillin in plasma of non-fasting volunteers after oral administration

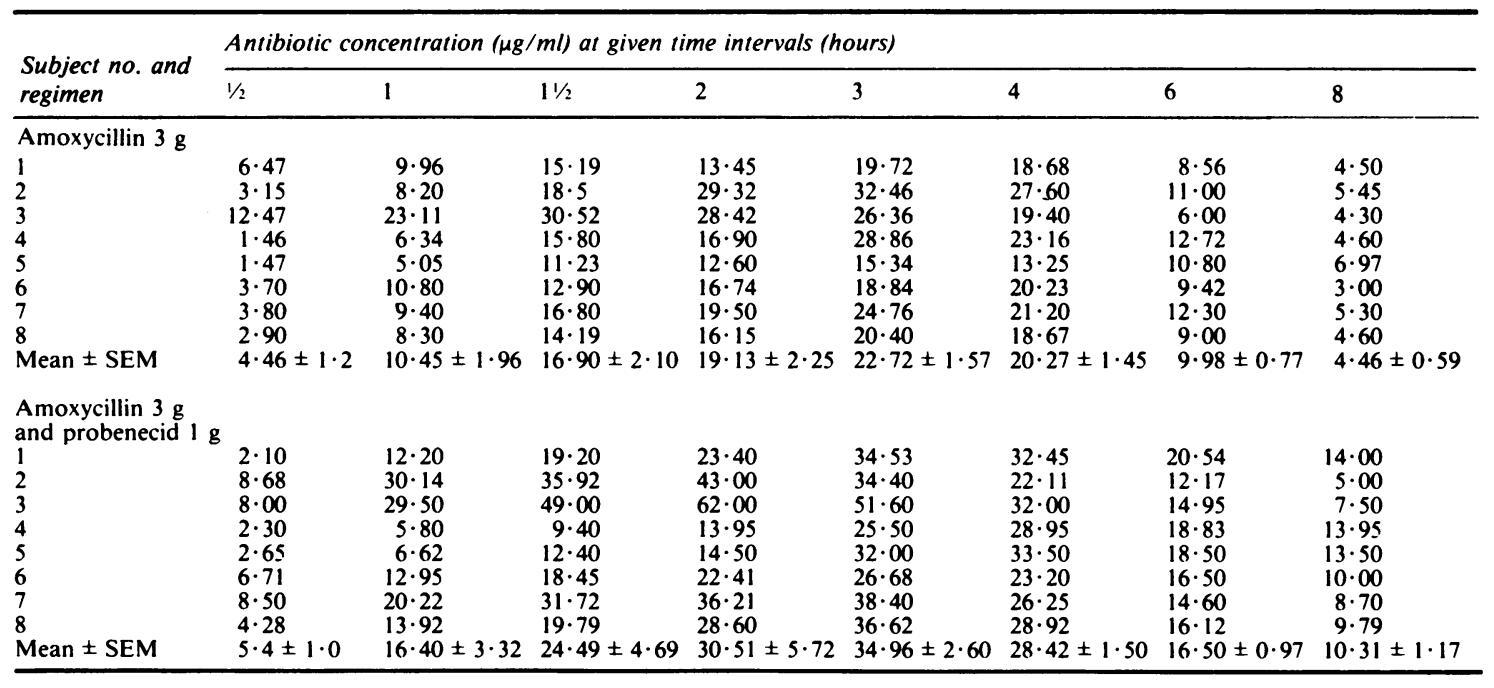


and $1 \mathrm{~g}$ probenecid were considerably higher than those achieved without concurrent administration of probenecid. After administration of $500 \mathrm{mg}$ and $1000 \mathrm{mg}$ amoxycillin, peak levels of $7.9 \mu \mathrm{g} / \mathrm{ml}$ and $12.0 \mu \mathrm{g} / \mathrm{ml}$ respectively after one hour have been reported (Verbist, 1974; Spyker et al., 1977). Vitti et al. (1974), however, reported $23 \cdot 1 \mu \mathrm{g} / \mathrm{ml}$ and $21 \cdot 4$ $\mu \mathrm{g} / \mathrm{ml}$ peak plasma levels at three hours after administration of $2 \mathrm{~g}$ amoxycillin with $0.5 \mathrm{~g}$ probenecid and $3 \mathrm{~g}$ amoxycillin alone respectively. In the same study the plasma concentration at eight hours with $2 \mathrm{~g}$ amoxycillin and $0.5 \mathrm{~g}$ probenecid combined was $3.8 \mu \mathrm{g} / \mathrm{ml}$ whereas that of $3 \mathrm{~g}$ amoxycillin was $1.8 \mu \mathrm{g} / \mathrm{ml}$. Probenecid, therefore, appeared to be blocking renal excretion and prolonging plasma levels. The mean peak plasma levels observed during the present investigation $(22 \cdot 7$ $\mu \mathrm{g} / \mathrm{ml}$ at three hours with $3 \mathrm{~g}$ amoxycillin without probenecid) is in close agreement with the findings of Vitti et al. (1974). In the present study, however, a mean peak level of $4.46 \mu \mathrm{g} / \mathrm{ml}$ amoxycillin was observed at eight hours for the dosage regimen without probenecid compared with that of $1 \cdot 80$ $\mu \mathrm{g} / \mathrm{ml}$ reported by the same author. Significantly higher peak plasma levels and area under the curves obtained for $3 \mathrm{~g}$ amoxycillin with $1 \mathrm{~g}$ probenecid than those for $3 \mathrm{~g}$ amoxycillin alone suggest better bioavailability with the former dosage regimen. The plasma levels were several times higher than the MIC values of most strains of gonococci sensitive to amoxycillin.

A correlation between low plasma levels, relative penicillin resistance, and increased failure rates in the treatment of gonorrhoea with previously adequate antibiotic regimens has been well documented (Eisenstein, 1977). Probenecid was introduced, therefore, to achieve a cure rate of over $95 \%$. Eagle et al. (1948) emphasised the importance of the duration of effective penicillin bactericidal levels, based on the fact that the cells need to be growing in order to be affected. Eriksson (1971) reported that it took at least five, and as long as 12, hours of bactericidal concentrations of ampicillin to cure gonorrhoea. Thus, the duration of antibiotic levels as well as their magnitude are important. The success of the recently conducted clinical trial for the treatment of gonorrhoea using a single oral dose of $3 \mathrm{~g}$ amoxycillin with $1 \mathrm{~g}$ probenecid (Thin et al., 1977) may be attributed, at least in part, to the higher and persistent plasma levels observed with such a dosage regimen.

\section{References}

Barbhaiya R. H., Turner P., and Shaw E. (1977). A simple, rapid fluorimetric assay of amoxycillin in plasma. Clinica chimica acta, 77, 373-377.

Burnell J. M. and Kirby W. M. M. (1951). Effectiveness of a new compound, Benamid, in elevating serum penicillin concentrations. Journal of Clinical Investigations, 30, 697-700.

Croydon E. A. P. and Sutherland R. (1971). a-amino-p-hydroxybenzylpenicillin (BRL 2333), a new semisynthetic penicillin: absorption and excretion in man. Antimicrobial Agents and Chemotherapy, 427-430.

Eagle H. (1948). Speculation as to the therapeutic significance of penicillin blood level. The direct baetericidal action of penicillin. Annals of Internal Medicine, 28, 260-278.

Eisenstein B. I. (1977). Effective treatment of gonorrhoea. Drugs, 14, 67-69.

Eriksson G. (1971). Oral ampicillin in uncomplicated gonorrhoea. IV Comparison of pharmacological and clinical results. Acta Dermatovenereologica, 51, 467-475.

Gordon R. C., Regamy C., and Kirby W.M.M.(1972). Comparative clinical pharmacology of ampicillin and amoxycillin administered orally. Antimicrobial Agents and Chemotherapy, 1, 504-507.

Karney W., Turck M., and Holmes K. K. (1974). Single dose therapy of uncomplicated gonorrhoea: Comparison of ampicillin and amoxycillin given with or without probenecid. Journal of Infectious Diseases, 129, (Supplement) S 250-259.

Neu H. C. and Winshell E. B. (1971). Pharmacological studies of 6(D(-)amino-p-hydroxyphenylacetimido) penicillanic acid in humans. Antimicrobial Agents and Chemotherapy, 423-426.

Spyker D. A., Rugloski R. J., Vann R. L., and O'Brien W. M. (1977). Pharmacokinetics of amoxycillin: Dose dependence after intravenous oral and intramuscular administration. Antimicrobial Agents and Chemotherapy, 11, 132-141.

Sutherland R., Croydon A. P., and Rolinson G. N. (1972). Amoxycillin, a new semisynthetic penicillin. British Medical Journal, 2, 13-16.

Thin R. N., Symonds M. A. E., Shaw E. J., Wong J., Hopper P.K., and Slocombe B. (1977). A double-blind trial of amoxycillin. British Journal of Venereal Diseases, 53, 118-120.

Verbist L. C. (1974). Triple crossover study on absorption and excretion of ampicillin, pivampicillin and amoxycillin. Antimicrobial Agents and Chemotherapy, 6, 588-593.

Vitti T. G., Garwath M. J., and Ronald A.R. (1974). Pharmacologic studies of amoxycillin in nonfasting adults. Journal of Infectious Diseases, 129, (Supplement) S 149-153. 